\title{
Centenario del nacimiento de Manuel José Othón
}

La intelectualidad mexicana ha celebrado este año, con numerosos y lucidos actos, el centenario del nacimiento del poeta Manuel José Othón.

El comité del centenario, que encabezó la Academia Potosina de Ciencias y Letras, tuvo como presidente al Sr. Antonio Castro Leal, profesor de la Universidad Nacional Autónoma de México, y contó con una comisión integrada con los siguientes miembros de honor:

Licenciado José Ángel Ceniceros, Secretario de Educación Pública;

Licenciado Antonio Carrillo Flores, Secretario de Hacienda;

Licenciado Gilberto Loyo, Secretario de Economía;

Don Manuel Âlvarez, Gobernador de San Luis Potosí;

Licenciado Raúl Rangel Frías, Gobernador de Nuevo León;

Licenciado Agustín Yáñez, Gobernador de Jalisco;

Doctor Nabor Carrillo, Rector de la Universidad Nacional de México;

Doctor Manuel Nava, Rector de la Universidad de San Luis Potosi;

Doctor Jaime Torres Bodet, Embajador de México en Francia.

Los homenajes contaron con el apoyo de las siguientes instituciones: Academia Mexicana de la Lengua; Instituto Nacional de Bellas Artes; Facultad de Humanidades de la Universidad de San Luis Potosí; Seminario de Cultura Mexicana; Instituto Potosino de Bellas Artes; El Colegio Nacional de México y la Fraternidad Universitaria Potosina.

Destacados académicos, profesores, críticos y escritores, en ciclos de conferencias y lecturas de la obra de Othón, integran la lista de los actos programados en la capital y el interior del país y que detallamos según la institución que los auspició y el lugar y fecha en que fueron cumplidos: 
En la Universidad Autónoma de SAN Luis Potosí:

1. El ambiente cultural de San Luis Potosi en la época de Otbón, Lic. José Francisco Pedraza, sábado 14 de junio.

2. Semblanza de Manuel José Otbón, Prof. Melchor Sánchez Jiménez, sábado 21 de junio.

3. Othón cuentista, Dra. Emma Susana Speratti, viernes 27 de junio.

4. El teatro othoniano, Prof. Luis Reyes de la Maza, viernes 4 de julio.

5. Otbón en el extranjero, Dra. Betenice Udick, miércoles 9 de julio.

6. La poesia otboniana, Profa. María del Carmen Millán, viernes 11 de julio.

7. El idilio salvaje, Dr. Joaquín Antonio Peñalosa, miércoles 16 de julio.

8. Otbón intimo, Lic. Rafael Montejano y Aguiñaga, viernes 18 de julio.

9. Otbón y sus críticos, Prof. Francisco González Guerrero, viernes 25 de julio.

En el Teatro de la Paz, San Luis Potosí, el 8 de julio: Mesa Redonda sobre "Othón modernista"; ponencia a cargo de la señorita María del Carmen Millán, profesora de la Universidad Nacional Autónoma de México. Discutieron el tema propuesto los siguientes participantes: Jorge Adalberto Vázquez, Joaquín Antonio Peñalosa, Jesús Medina Romero y Félix Douajare Torres.

En la Academia Mexicana de la lengua, en la sede de dicha institución, el 11 de julio:

Presidió el acto Don Alfonso Reyes, presidente de la alta corporación mexicana, quien presentó a los participantes y comentó sus ponencias ante familiares del poeta y numeroso público. Fueron oradores oficiales del acto los académicos Joaquín Antonio Peñalosa, quien disertó sobre el "Idilio salvaje", y Francisco Monterde, quien lo hizo sobre la "Elegía a Rafael Ángel de la Peña".

En el Palacio de Belias Artes, en la ciudad de México, el 14 de junio, se dio el siguiente programa:

1. Capricho italiano (Tschaikowsky). Orquesta Sinfónica Nacional. Director: Salvador Ochoa.

2. Himno de los bosques (Manuel José Othón). Voz: Víctor Mallatino.

3. El centenario del nacimiento del poeta Manuel José Otbón, Sr. Antonio Castro Leal.

4. Canto de amor y muerte. Arreglo de Luis Sandi. Coro de Madrigalistas. Dirección: Luis Sandi.

5. En el desierto (Idilio salvaje) y otros poemas (Manuel José Othón). Voz: Carlos Pellicer.

6. Nocbe rústica de. Walpurgis (Manuel José Othón). A voces alternas con fondo musical a cargo de la Orquesta Sinfónica Nacional. Director: Salvador Ochoa. 
Director de la escenificación del poema: Salvador Novo. Voces: María Douglas, Salvador Novo.

En el mismo Palacio de Bellas Artes, sala Manuel M. Ponce, LA Fraternidad Universitaria Potosina tuvo a su cargo los siguientes actos:

Miércoles 9 de julio: La obra dramática de Manuel José Othón, Prof. Luis Reyes de la Maza.

Miércoles 16 de julio: El tema vital de Otbón, Profa. Bernice Udick.

Miércoles 23 de julio: El paisaje sinfónico de Manuel José Otbón, Profa. María del Carmen Millán.

Miércoles 30 de julio: Los cuentos de Manuel José Otbón, Prof. Enrique González Casanova.

Miércoles 6 de agosto: Las imágenes en la poesia de Manuel José Otbón, Lic. Manuel Calvillo.

Miércoles 13 de agosto: Las influencias literarias en la obra lírica de Manuel José Othón, Lic. Manuel Ramirez Arriaga.

Miércoles 20 de agosto: Las cauces poéticos de Otbón, Prof. Luis Noyola Vázquez.

Fue maestro de ceremonias el Lic. Roberto Monsivais A.

\section{NOTICE TO MEMBERS}

PLEASE patronize our advertisers and thus contribute to the financial support of your institute. Our advertisers have splendid collections of Latin American books at prices no higher than you would elsewhere. When ordering from them, please mention the REVISTA.

$$
\text { THANK YOU }
$$


